\title{
BIR ANAYASA TASLAĞINA KARŞI OY YAZISI
}

\author{
Prof. Dr. Hilkmet Sami TÜRK*
}

\section{$S U \mathcal{N} U S$}

1961 Anayasast'ndan bu yana Türkiye, ortalama her on yzlda bir ya köklü bir anayasa değişikliği, ya da yeni bir anayasa yapan bir illke durumundadtr. 1982 Anayasast'nen onuncu ynlinda da Türkiye'nin gündeminde anayasa değişikliği var.

20 Ekim 1991 milletvekili genel sesiminden sonra ortak bir hïktimet kuran DYP ve SHP arastnda imzalanan Koalisyon Protokolünde 1982 Anayasast'nn ülke gereksinmelerinin gerisinde kaldiğı; siyasal partiler, ilgili diğer kuruluşlar ve halktn uzlaşmasıyla hukukun üstünliğ̈ï ilkesine dayal," "tam demokratik" ve goğulcu, 乌̧ăgdas bir anayasa hazurlanmasz gerektiği belirtilmistir (bk. Cumhuriyet, 20.11.1991, s. 15 "Koalisyon Protokolünün Tam Metni"). Başbakan Süleyman Demirel tarafindan 25 Kastm 1991 günü TBMM'de okunan Hükümet Programi'nda da äzetle Tiükiye'nin "săgdas ve tam demokratik bir sivil toplum anayasast ihtiyact içinde" olduğu, Hükümetin ilkeyi böyle bir anayasaya kavusturabilmek igin TBMM'de bütïn olanaklan kullanmaya hazır olduğu "Türk milletine beyan" edilmistir. Bu genel açzlama yaninda özel radyo ve televizyon istasyonlarmen kurulmast, ögretmenlerin sendika kurmalan, üniversite öğretim üyelerinin siyasal partilere üye olabilmeleri gibi özel önem verilen geşitli konularda anayasa değisiklikleri yaptlacağı, Program'da aynca vurgulanmistur (bk. T.C. Resmí Gazete, 1.12.1991, S. 21068 , s. 2 vd, 4, 2I).

Aslinda her iki parti, daha muhalefot ytllannda yeni bir anayasa veya kapsamlı anayasa değisiklikleri yapnlmass yolunda bazi hazarlhk galusmalan yürütmüs bulunmaktader. Ömeğin SHP, 1989 ynlında yeni bir anayasa taslağz haztrlamak iuzere bir Anayasa Komisyonu olusturmuştu. Ilk toplantusint 20 Ekim 1989 günü yapan Komisyon, I Nisan 1991 günü galişmalarnt tamamlayarak hazarladiğ Anayasa Taslağt'n genel gerekgesi ve madde gerek-

(*) Ankara Unniversitesi Hukuk Fakültesi Orretim Uyesi. 
celerigle birlikte Parti Genel Başkanliğtna sunmuştur. Taklaşik onsekiz allhk bir çalş̧mann ürünü olan ve Başlangı̧ ile 170 madde ve 7 gegici maddeden oluşan taslağa bazi üyelerin farklı görüslerini yansitan karşı oy yaztlan da eklenmisti. Bu Taslaktan hareket etmek suretiyle SHP Merkez Tïrïtme Kurulu'nca haztrlanan ve 23-24 Nisan 1991 günleri toplanan Parti Meclisi'ndr göriusiulerek benimsenen "Anayasa Temel Hlkeler Önerisi", daha sonra bir kitapg̨k halinde yaytmlanmıştır.

Eğer Anayasa Komisyonu'nca hazırlanan Taslağın asl metni de, gerekgeleri we karşı oy yazalaryyla birlikte olduğu gibi yaymlansaydt; getirdiği öneriler ve değı̆şik seçeneklerle anayasa değişikliği tartı̧̧alarinn somut çözümlere yönlendirilmesi bakımından büyük yarar sağlayabilirdi. Ancak aradan bir yula yakin bir zaman gę̧mesine karșn taslak henüz yaymlanmamışır.

Bu durumda sözü gȩ̣en Anayasa Komisyonu çalş̧malarna katzlmus ve bazı konularda Komisyon coğunluğundan aynlan görüslerini bir "Karşı Oy raziss" ile ifade etmiş bir kimse olarak, anayasa değişikliğinin ciddi bişimde Türkiye gündemine girmesigle bu görüsleri agtklama zamantnn da geldiği kantsindayzz. 5 Nisan 1991 tarihini taşzyan bu "Karş Oy Yaztsı", üzerinde herhangi bir değisiklik yapilmaksizın, fakat sadece değinilen konularn kolayca izlenebilmesi igin ilgili madde numaralarmm yanına köseli parantez iģinde uygun kenar başlıklart konmus olarak yaymlanmaktadır. Sunduğumuz "Karşz

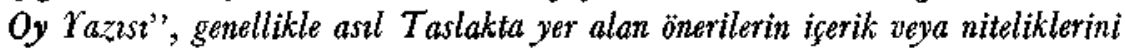
de yanstmaktadtr. Böylelikle asal Taslak metninin birlikte yaymlanmamasin-

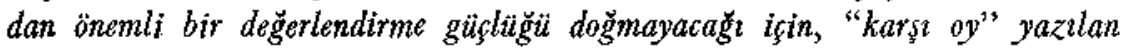
maddeleri tamticu dipnotlan verilmesine gerek görillmemiştir.

Bu çerçeve içinde yaymladığımız "Karşı Oy razzsı" ile anayasa değisikliği tartı̧malarına kïgulk bir katkıda bulunmay umuyoruz.

Ankara, Mart 1992 


\section{KARŞI OY YAZISI}

\section{GENEL OLARAK}

1876 'dan bu yana 115 yıllık bir yazılı anayasalar 'geçmişi olan Türkiye, yeni bir anayasa arayışı içindedir. Böyle bir anayasa ile ilgili hazı̊lık çalş̧maları, dünyada ve Türkiye'de çok büyük değişikliklerin yaşandığı, şimdiye değin sarsılmaz sanılan sistemlerin ve değerlerin yıkıldığğ bir döneme rastlamaktadır. Bu değişim ve oluşum süreci, henüz tamamlanmı değildir. Dolayısıyla böyle bir dönemde çă̆ın gereklerine ve ülke koşullarına uygun yeni bir anayasa hazxrlamak, son derece dikkatli olmayı gerektiren bir i̧̧tir. Böyle bir anayasa, dünyadaki büyük değişimi yansıtacak, yenilikleri benimseyebilecek kadar açık düşünceli ve çağdaş; ülke koşullarını ve gereksinmelerini göz ardı etmeyecek kadar gerçekci; yalnız en son olaylara tepki niteliğj taşsmayacak, düzenlediği konulari en az 115 yıllık bir yazılı anayasaclık birikimiyle değerlendirecek, hatta başka ülkelerin deneyimlerinden yararlanacak kadar geniş açılı, dengeli ve yapıcı olmak zorundadır.

Böyle bir anayasanın düzenlediği devlet de, insan hak ve özgürlükleri ile toplumsal refahı gerçekleştirmeyi temel amaç edinen, insan hak ve özgürlüklerini onlara yönelik tehlikelere karşı koruyabilecek güçte olan, bütün organ ve kurumlarıyla işleyen ve değişen dünyaya ayak uydurabilen bir devlet olmalıdir.

SHP Anayasa Komisyonu'nca hazırlanan Anayasa Taslağı bu anlayışla ele almndığında, çeşitli konularda farkh görü̧ ve öneriler getirilebilir. Bunların başlıcalari, Taslağın maddeleriyle bağlantılı olarak şöyle sıralanabilir: 


\section{TASLAK'TAN AYRILAN GÖRÜŞ VE ÖNERİLER}

\section{Madde 8 [Yürütme Yetki ve Görevi]}

Devletin üç temel erki arasında ayırım yapılması ve yasama ve yürütmenin "yetki" olarak nitelenmesine karşıllk yürütmenin sadece "görev" olarak nitelenmesi, 12 Eylül 1980 döneminin yürütmeyi güçlendirme eğilimine karşı bir tepki ve yürütme organına güvensizliğin ifadesi niteliğindedir. Bu, yürütmenin seçilmiş bir parlamentonun güveniyle çalışması olgusuyla çelişen bir yaklaşımdır. Taslağın diğer maddelerinde de yürütme organını zayıflatıcı hükümler yer almaktadır. Yasa gücünde kararnamelerle ilgili hükümlerdeki aşırı kısıtlamalar, bu yaklaşıma örnek olarak gösterilebilir (m.91).

Hızla değişen bir çağın gereklerine uyabilmek için yürütme organının yeterince güçlü olması gerekir. Yürütmeyi aşırı derecede zayıflatmakla bir yere varılamaz. Ayrıca yürütme organının yeterince güçlü olmamasının uzun vadede totaliter rejimlere elverişli bir ortam yarattığı, tarihî bir gerçektir.

Bu nedenlerle maddenin 1982 Anayasası'nda ve Taslağın ilk metninde olduğu. gibi "Yürütme yetkisi ve görevi, ..." ibaresiyle başlaması, uygun olacaktır.

\section{Madde 10 [Yasa Onünde Eşitlik]}

Maddenin 1. fikrasına 2. cümle olarak kadın-erkek hak eşitliğini vurgulayan şu cümlenin eklenmesi, çağdaş anlayışa uyguiı olacaktır:

"Erkekler ve kadınlar, eşit haklara sahiptirler".

Nitekim 1949 Alman Anayasası da, cinsiyet ayırımı yasăğ yanında kadın-erkek hak eşitliğini ayrıca belirtmiş̧ir (Grundgesetz m.3/2-3).

\section{Madde 13 [Temel Halk ve Orgürlüklerin Smmrlanması]}

1. Maddenin I. fikrasmm konusu itibariyle 12. maddenin sonuna eklenmesi, daha doğru olur.

2. Taslağın hazırlanması sırasında en çok tartışılan, hatta Komisyon çoğunluğunun görüş değiştirmesine yol açan konu, temel hak ve özgürlüiklerin sınırlanması sorunu olmuştur. Komisyon çoğunluğunun son olarak kabul ettiği çözüm, ancak ilgili maddelerde öngörülen nedenlerle sinırlama yöntemidir. Bu yöntem, Türkiye'nin ileride karşlaşabileceği ve her birinin önceden tahmini çok güç çeşitli olasılık- 
ların gerektireceği önlemlerin alınabilmesi bakımından yeterince esnek değildir. Ayrıca bu yöntem, temel hak ve özgürlüklerin yalnız Anayasa'nı ilgili maddelerinde düzenlenenlerden ibaret olduğu biçiminde örtülü bir sınırlamayı da içermektedir. Üstelik bu yöntem, temel hak ve özgürlüklerin her birine ilişkin sınırlama nedenlerinin ayrı ayrı gösterilmesi sonucunda ilgili maddelerin uzamasına ve ă̆ırlaşmasına yol açmıştır. Oysa genel sımırlama nedenleri de kabul edilmiş olsaydı, her hak ve özgürlükle ilgili mađdede sadece o hak ve özgürlüğe özgü tjpik smırlama nedenlerinin belirtilmesiyle yetinilebilirdi.

Bu konuda -1961 Anayasası'nı 22.9.1971 tarih ve 1488 sayılı Kanun'la değişik 11. maddeside olduğu gibi- genel ve özel sınırlama nedenleri yöntemlerine birlikte yer veren, ancak yeterli denge öğelerini de getiren bir sistem daha uygun olacaktır. Komisyon çoğunluğunun başlangıçtaki eğilimini de yansıtan aşağıdaki metin, böyle bir sisteme dayanmaktadır:

\section{"II. Temel Hak ve Ögürlïklerin Sintrlanmast}

Madde 13 - Temel hak ve özgürlükler, Devletin ülkesi ve milletiyle bölünmez bütünlüğünün, Cumhuriyetin, millî güvenliğin, kamu düzeninin, kamu yararının, genel ahlâkın ve genel sağlı̆̆ın korunması amacıyla veya Anayasanın diğer maddelerinde öngörülen özel nedenlerle, Anayasanın sözüne ve ru* huna uygun olarak, ancak yasayla sinırlanabilir.

Temel hak ve özgürlüklerle ilgili sınırlamalar, demokratik toplum düzeninin gereklerine, her hak ve özgürlügüun kendine özgü niteliğine aykırı olamaz ve öngörüldükleri amaç dışında kullanılamaz.

Hangi nedenle olursa olsun yasa, temel hak ve özgürlüklerin özüne dokunamaz."

\section{Madde 17 ve 48 [Zorla Galıştırma Yasağı - Çalışma Hak- la ve Odevi]}

Vatandaşlık ödevi niteliğindeki çalışmalarla ilgili hüküm, hem 17. maddenin II. fikrasinda, hem 48. maddenin III. fikrasinda yer almaktadır. Gereksiz yinelemeden kaçımmak için 48. maddenin III. fikrasının Taslak'tan çkarılması gerekir. 


\section{Madde 45 [Devletleştirme ve Özelleştirme]}

Devletleştirme ile ilk kez belirli anayasal kurallara bağlanan özelleştirme arasında kamu yararının derecesi bakımından yaratılan fark, karma ekonominin mantığ ve ekonominin sürekli yeniden yaplanma gereksinmesi açısından yerinde sayılamaz. Nitekim 1958 Fransız Anayasasi, devletleştirme ve özelleştirme ile ilgili kurallarm yasayla konacağını -aralarında fark gözetmeksizin - belirtmiştir (Constitution m. 34). O nedenle maddenin I. fikra 1 ve 2. cümlelerinin aşağıdaki biçimde birleştirilmesi uygun olur:

"Madde 45 - Kamu yararınm gerektirdiği durumlarda kamu hizmeti niteliği taşıyan özel teşebbüsler devletleştirilebilir; kamu hizmeti niteliği taşımayan kamu iktisadí teşebbüsleri özelleştirilebilir. ..."

\section{Madde 47 [Çalışma ve Sözleşme Ozgürlüğ̈ü]}

I. fikrada çalı̧̧̧ma özgürlüğünden söz edilmemesi eksik, özel teşebbüs kurma özgürlüğünün "işkurma özgürlüğü" olarak ifade edilmesi yanıltıcıdır. Özel teşebbüs kurma özgürlüğü, kişilerin bireysel veya ortaklık biçiminde işletmeler kurma özgürlüğüdür. $O$ nedenle 1982 Anayasası'nın 48. maddesinin Taslağın ilk metninde de benimsenmiş olan I. fikrası korunmalı ve maddenin kenar başlığ göre değiştirilmelidir.

\section{Madde 48 [Calışma Hakkı ve Odevi]}

1. Maddenin II. fıkrasının son bölümünün 2. cümle olarak şöyle tamamlanması uygun olur:

"... Devlet, çalışmayı destekler, tam istihdamı gerçekleştiriçi ve işsizliği önleyici tedbirleri alır; işsizlik sigortası kurar."

2. Maddenin III. fikrası için bk, yuk. "Madde 17 ve 48 ".

\section{Madde 52 [Grev Hakk1]}

Taslakta dolayl bir biçimde memurlara ve diğer kamu görevlilerine de grev hakkı tanımmaktadır. Bu, Devlet ve diğer kamu tüzel kişilerince yürütülen kamu hizmetlerinin sürekliliği ilkesiyle bağdaşmayan sakıncalı bir hükümdür (krş. Taslak m. 127). Kayda değer ki, henüz Türkiye tarafindan onaylanmayan 151 sayılı Kamu Kesimin- 
de Çalışma Koşullarının Belirlenmesi İçin Usuller ve Örgütlenme Hakkımı Korunmasına İlişkin ILO Sözleşmesi'nde kamu görcvlilerinin çalş̧ma koşullarinın düzeltilmesine elverişli yöntemler üzerinde durulmakla birlikte, memurlara grev hakkı tanınmamıştır (krş. m.7 ve 8 ). O nedenle grev hakkınm işçilerle sımırl tutulması ve memurlarla diğer kamu görevlileri için - Taslak'ta "Sendika Kurma Hakkı" açısından yapıldı̆̆ı gibi (m.50/II) - şu yolda bir hüküm konması uygun olur:

"Memurlar ve işçi niteliği taşımayan diğer kamu görevli- lerinin bu alandaki hakları yasayla düzenlenir".

\section{Madde 65 [Orman Köylüsünün Korunmas1]}

"Orman Köylüsünün Korunması". ile ilgili bu madde, konusu itibariyle, ya "Tarım, Hayvancılı ve Bu Üretim Dallarında Galışanların Korunması" ile ilgili 41., ya da "Orman ve Ormanlarrr Korunması, Geliştirilmesi" ile ilgili 166. maddeden sonra gelmelidir.

\section{Madde 68 [Seçme, Seçilme ve Siyasal Faaliyette Bulunma Hakdart]}

Seçim veya halkoylaması günü sandık başına gidemeyecek durumda olan veya seçim çevresinde bulunmayan, özellikle yurt dışnda çalışan vatandaşların mektup veya vekâlet yoluyla oy kullanmalarına olanak vermek üzere maddenin II. fıkrasına aşă̆ıdaki hükmür eklenmesi yerinde olur:

"Oy hakkının mektup veya vekâlet yoluyla kullanılması, yasayla düzenlenir."

\section{Madde 69 ve 129 [Parti Kurma, Partilere Girme ve Par- tilerden Çakma - Yäkseköğretim Kurumlar]}

Kamu görevlileri için konan siyasal partilere üye olma yasă̆ından üniversite öğretim elemanlarının "hariç" tutulması, bir ayrıcalık niteliği taşıdı̆̆ kadar onların öğrencilerin gözünde sahip olmalari gereken tarafsızlıkla da bağdaşmaz. Siyasal hayatın gelişmesine bilimsel katkılarla yardımci olmak için siyasal partilere üye olmak gerekmez.

Öte yandan öğretim üye ve yardımctlarmın "ancak" siyasal partilerin genel merkez organlarında görev alabileceklerini belirten 
bit hüküm, 129. maddenin son fikrasında yer almaktadır. Eğer bunda bir yarar görülüyorsa, o hükümdeki "ancak" sözcügüünün çıkarılması yeterlidir.

\section{Madde 76 [Milletvekili Seçilme Yeterliği]}

1. 68 ve 69 . maddelerde seçme ve siyasal partilere üye olma yaşı 18'e indirilirken, bu maddede millvetvekili seçilme yaşının 30'da brrakılması bir çelişkidir. Anılan değişikliklerle birlikte milletvekili seçilme yaşının da 25 'e indirilmesi, siyasal hayata dinamizm getireceği gibi; gençlere meşru zeminlerde mücadele vermek suretiyle ülke yönetiminde etkili olma olanağını getirecektir. Kayda değer ki, çeşitli ülkelerde parlamento üyeliğine seçilme yeterliği, oldukça genç yaşlarda başlamaktadır. Öneğin Amerika Birleşik Devletleri'nde Temsilciler Meclisi üyeliği, İtalya'da milletvekilliği için 25 yaş (Constitution of the United States, Art. I Section 2; Costituzione della Repubblica Italiana m.56/III), Fransa'da milletvekili seçilmek için 23 yałs (Constitution m. 25/1I; Ordonnance no. 58-998 du 24 octobre 1958, portant loi organique relative aux conditions d'éligibilité et aux incompatibilités parlementaires, m.2), Almanya'da Federal Meclis, Isveç'te Riksdag üyeliği için 18 yaş yeterli sayılmıştır (Grundgesetz m. 38, Bundeswahlgesetz § 15/2; Regeringsformen 3 kap. 2, $10 \S \S$ ).

2. Aynı maddede milletvekili seçilme yeterliğinin orta öğrenimin tamamlanmış olmasına, daha açık bir deyişle, lise mezuniyetine bağlanması, demokratik sayılamayacak bir kısıtlamadır. Şimdiki ilkokul mezunu olma koşulu yeterlidir. Kaldı ki Türk toplumunda ilkokul mezunu olduğu halde .nilletvekilliği görevini lise, hatta üniversite mezunlarından daha liyakatle yerine getirecek bilgi ve deneyime sahip nice insanlar vardır.

\section{Madde 78 [TBMM Ara Seçimleri]}

TBMM üyeliklerinde meydana gelen boşalmalarm doğrudan doğruya ara seçimleriyle doldurulması usulü, ara seçimlerin fïlen tek adlı çoğunluk sistemine göre yapılması nedeniyle nispî seçim sistemiyle çelişen adaletsiz sonuçlar vermekte; üstelik TBMM'nin uzun süreler boyunca üye tamsayısının altında milletvekili sayılarıyla çalışmasma yol açmaktadır. Buysa, iktidar ve muhalefet partileri arasındaki milletvekili sayıları farkınn çok az olduğu durumlarda hükümetin kaderinin rastlantılara bırakılması demektir. But sakmcaları 
gjdermek için çeşitli ülkelerin parlamentolarında ve bizde yerel yönetim meclislerinde meydana gelen boşalmaların öncelikle yedeklerle doldurulması, buna olanak kalmayan durumlarda ise ara seçime gidilmesi usulü uygulanmaktadır. Aynı usulün milletvekilliklerinde meydana gelecek boşalmalarda da benimsenmesi yararlı olacaktır. (Bu konuda ayrıntılı bilgi için bk. Hikmet Sami Tïrk, "Açık Parlamento Üyeliklerinin Ara Seçimleri Yoluyla ya da Yedeklerle Doldurulması", A.Ü. Hukuk Fakültesi Dergisi, C. 38, 1981 (1983), S. 1-4, s.3-51). O nedenle maddenin II ve III. fikralarının aşağıdaki biçimde düzenlenmesi uygun olur:

"Türkiye Büyük Millet Meclisi üyeliklerinde meydana gelen boşalmaların yedeklerle doldurulamaması durumunda ara seçime gidilir. Ata seçim, her seçim döneminde bir kez yaptlır ve genel seçimden yirmidört ay geçmedikçe ara seçime gidilemez. Ancak boşalan ve yedeklerle doldurulamayan üyeliklerin sayısı, üye tamsayısınm yüzde üçünü bulduğu zaman ara seç:min üç ay içinde yapılmasına karar verilir. Genel seçimlere bir yrl kala ara seçim yapılamaz.

Boşalan üyeliklerin seçimde bunları kazanmış olan siyasal partilerin aday listelerinden dolduruIması usulü, yasayla düzenlenir."

\section{Madde 91 [Yasa Gücünde Kararname Ģkarma Yetkisi]}

1. Maddenin I. fikrasında "Anayasada yasayla düzenleneceği bildirilen konular", yasa gücünde kararnamelerle düzenlenemeyecek konuların başında sayılmıştır. Bu, yasa gücünde kararname kurumunun fiilen kaldırılması anlamma gelen bir değişikliktir. Cüunkü yasa gücünde kararname için yetki yasası çıarırlması, _yine aynı maddede belirtilen temel haklar, kişi hakları ve ödevleri, siyasal haklar ve ödevler hariç olmak üzere- özellikle Anayasa'da yasa ile düzenleneceği belirtilen konularda gereklidir.

Yasa gücünde kararname yolunun son zamanlarda kötüye kullanılması, aslında özellikle ivedi düzenlemeyi gerektiren teknik konularda yararlı olabilecek bir yolun tamamiyla kapatılmasna neden olmamalıdır. Kayda değer ki, çă̆ımızın çeşitli anayasalarında yürütme organına benzer nitelikte oldukça geniş düzenleme yetkileri verilmiş veya verilmesine olanak tanınmıştır. Örneğin 1947 ttalyan ve 1958 Fransız anayasalarında bu yolda hükümler vardır (Costituzione della 
Repubblica Italiana m. 76-77, Constitution m. 37-38). O nedeulc maddenin I. fıkrasmdaki "Anayasada yasayla düzenleneceği bildirilen konular" ibaresi, metinden çkarılmalıdır.

2. Yasa gücünde kararnamelerin yasaya çevrilmesi için öngörülen 90 günlük süre yetersizdir. Bu sürenin 6 aya çıarılması uygun olur. O takdirde Meclis'in yasa gücünde kararname görüşmek üzere olağanüstü toplanmasina da gerek kalmayabilir.

\section{Madde 101, 102 [Cumhurbaşkanı Seçimi]}

Cumhurbaşkanı seçimi Türkiye'de çok tartışılan bir konu olduğu halde, Komisyonca her turda üçte iki toplantı yetersayısı aranması dışında bir yenilik getirilememiştir. Yeni hükmün çoğunluk partisini toplantıya katılmayan muhalefetle anlaşmaya gitmek zorunda bırakacağ̀ düşünülmüştür.

Ancak böyle bir uzlaşma gerçekleşmez ve Cumhurbaşkanı seçimi öngörülen süre içinde yaptlamazsa, milletvekili genel scçiminin yenilenmesi kaçınılmaz olacaktır. Anayasasında böyle bir sisteme ilk kez. yer veren Yunanistan'daki son Cumhurbaşkanı seçimi, siyasal partilerin kendi adaylarmda israrlı olabileceklerini ve uzlaşmaya yanaşamayabileceklerini, o nedenle de ülkenin arka arkaya seçim yonilemek zorunda kalabileceğini göstermiştir.

Cumhurbaşkanının doğrudan doğruya halk tarafindan seçilmesi, rejimin niteliğini de etkileyebilecek köklü bir değişiklik sayılsa da; parlamenter sistem çerçevesinde bazı alternatif çözüimler üzerinde durulmalidir.

Kanaatimizce Cumhurbaşkanı, TBMM üyeleriyle il genel meclislerinin kendi üyeleri arasından seçecekleri aynı sayıda il temsilcilerinden oluşacak bir Cumhuriyet Kurultayı'nca seçilebilir. TBMM üye tamsayısı Taslak'ta öngörüldüğü gibi 500 olarak kabul edilirse, Cumhuriyet Kurultayı da 1.000 üyeden oluşacaktır. Her ilden o ilin milletvekili sayısı kadar il temsilcisi Cumhuriyet Kurultayı'na katılacaktır. $\mathrm{Bu}$ temsilciler, kendi içlerinde, partilerin veya bağımsızların il genel meclislerindeki üye sayılarıyla orantılı olarak belirlenecek kontenjanlara, başka bir deyişle, nispí temsil ilkesine göre seçilmiß̧ olacaklardır. 11 genel meclislerince Cumhuriyet Kurultayı'na gönderilecek il temsilcilerinin seçimi, Cumhurbaşkanı seçiminin yenilenmesini gerektiren durumun özelliğine göre belli bir tarihte il seçim kurullarının gözeti- 
minde yapılacak ve seçilen il temsilcilerinin adları Yüksek Seçim Kurulu'nca ilân edilecektir. Böylece oluşan Cumhuriyet Kurultayı, TBMM Başkanının çağrısıyla TBMM Genel Kurul Salonunda toplanacaktir. Gizli oyla yapılacak seçim için bir günde ya da en çok üç günde arka arkaya yapılacak üç oylama yeterlidir. Ilk oylamada Kurultay üye tamsayısının üçte ikisi, ikinci oylamada salt çoğunluğu aranacaktır. Ilk iki oylamada Cumhurbaşkanı seçilemediği takdirde ikinci oylamada en çok oy almış iki aday arasında yapılacak üçüncü oylamada en çok oy alan, Cumlıurbaşkanı seçilmiş sayılacaktır.

Milletvekili ve yerel genel seçimler —bugün olduğu gibi- ayrı ayrı zamanlarda yapılmak kaydıyla böyle bir sistem, kamuoyunun olabildiğince tam bir kesitini Cumhurbaşkanı seçimine yanstabilecek, siyasal partileri uzlaşmaya yönlendirebilecek, ayrıca yereI yönetimleri güçlendirebilecek bir sistemdir. Ekleyelim ki böyle veya benzeri sistemler, Avrupa'da yine parlamenter rejimle yönetilen Almanya ve Italya'da da uygulanmaktadır (Grundgesetz m. 54, Costituzione della Repubblica Italiana m. 83).

\section{Madde 119 [Cumhurbaşłanının Sorumluluğu ve Sorum- suzluğgu}

Türkiye Cumhuriyetini ve Türk ulusunun birliğini temsil eden Cumhurbaşkanının vatana ihanetle suçlanması veya makamının boşalmı̧ sayılması, son derece önemli ve istisnaî olaylardır.

I. Maddenin II. fikrasında Cumhurbaşkanının vatana ihanetle suçlanması için --1961 Anayasası'nın 99 ve 1982 Anayasası'nın 105. maddelerinde olduğu gibi- TBMM üye tamsayısının üçte birinin önerisi koşulunun aranmaması, aynı zamanda III. fukrayla çelişen bir eksikliktir.

2. III. fikra gereğince Cumhurbaşkanı makammın boşalmıs sayılması için son sözün Anayasa Mahkemesi'ne bırakılması, özellikle tarafszlığın yitirilmesi gibi tartışmaya elverişli bir konuda yalnız siyasal nitelikte bir kararla yetinilmeyerek bu durumun aynı zamanda Yüce Divan işlevini gören yargı organının karanyla saptanması bakımından yerinde olur. Bu, Cumhurbaşkanı için her seçimle değişebilecè parlamento çoğunlukları karşısında bir güvencedir de. Nitekim Almanya'da da Federal Cumhurbaskanının Anayasayı ve federal bir yasayı kasıtlı olarak çiğnemekle suçlanması durumunda Federal Mec- 
lis veya Federal Konsey'in kararıyla yetinilmemiş; son söz, Federal Anayasa Mahkemesi'ne bırakılmıştır (Grundgesetz m. 61).

3. III. fıkrada yeni Cumhurbaşkanı seçimi ve TBMM Başkanının Cumhurbaşkanı vekilliği ile ilgili olarak yer alan hükümler, bu konular zaten başka maddelerde düzenlendiğinden gereksizdir (krş. Taslak m. 102, 106).

\section{Madde 119, 120 [Olağanüistii Yönetim Usulleri]}

Olağanüstü durum ve sıkıyönetim süresinde Bakanlat Kurulınun bir yetki yasası olmadan da, başka bir deyişle, doğrudan doğruya Anayasa ile verilmiş yetkiyle yasa gücünde kararname çıarabilmesi, Komisyon'da en çok tartışılan konulardan biri olmuştur. Şimdiye kadarki uygulamada bu yetkinin kötüye kullanılmış olması, sağlıkhı bir dcğerlendirmeye engel olmamalıdır. Türkiye gibi kritik bir jeopolitik konumda bulunan bir ülkenin karşı karşıya gelebileceği çok ăğı bazı tehlikeler, Bakanlar Kurulunun kendi sorumluluğu altunda durumun gerektirdiği ivedi önlemleri almasını zorunlu kılabilir. Kötüye kullanmayı önleyici denge öğelerine yer vermek kaydıyla yürütme organından bu yetkiyi esirgememek gerekir. Nitekim benzeri bir düzenleme, Italyan Anayasası'nda da yer almaktadır (Costituzione della Repubblica Italiana m. 77). O nedenle 119 ve 120 . maddelerin sonunda ayr birer fikra ya da olağanüstü yönetim usulleri ile ilgili 117-120. inaddelerden sonra ayrı bir maddede ortak hüküm olarak şöyle bir düzenlemeye yer verilmesi uygun olur:

"Olağanüstü durum veya sıkıyönetim süresinde Cumhurbaşkanının başkanlığında toplanan Bakanlar Kurulu, olağanüstü durum veya sıkıyönetimin gerekli kıldığı yasa gücünde kararnameler çkarabilir. Bu kararnameler, Resmî Gazete'de yayımlanır ve aynı gün Türkiye Büyük Millet Meclisine sunulur. Meclis toplanık değilse derhal toplantıya çağrılır. Onbeş gün içinde yasaya çevrilmeyen yasa gücünde kararnameler, kendiliğinden yürürlükten kalkar."

\section{Madde 124 [tdari İ̧lemlere Karşı Yargı Yolu]}

Maddenin IV. fikrasımın "Idari işlemin açıkça hukuka aykırı olması..." biçiminde başlatılması, yürütmenin durdurulması kararı koşulları arasında paralellik sağlanması bakımından yerinde olur. 


\section{Madde 126 [Yerel Yönetimler]}

III. fıkra gereğince yerel genel seçimlerin TBMM genel seçimleriyle birlikte yapılmașı, yerel yönetimlerin istikrar içinde çalışabilmeleri için gerekli görev süresi güvencesiyle bağdaşmaz. Çünkü milletvekili genel seçimleri, örneğin iktidar ve muhalefet partileri arasındaki siyasal bir tartı̧̧mayı ulusun hakemliğine sunmak, bir hükümet bunalımına çòzüm bulmak gibi değişik siyasal nedenlerle TBMM veya Cumhurbaşkanı kararryla yenilenebilir (krş. Taslak m. 77, 111). Kendileriyle hiçbir ilgisi olmayan nedenler yüzünden yerel yönetim organlarınun görevlerine son vermek ve onları da yeni seçime zorlamak anlamsız ve sakıncalıdır. O nedenle - şimdiye kadar olduğu gibi- milletvekili genel seçimleriyle yerel genel seçimleri ayrı ayrı tarihlerde yapmak, hem daha sağlklı, hem aradaki zaman içinde kamuoyundaki değişimlerin ifadeșine olanak vermek bakımından daha yararlıdır. Kaldı ki milletvekili genel seçimleriyle yerel genel seçimleri bağlantılı duruma getirmek, yerel yönetimlerin sorunlarının arka planda kalmasına ve yerel seçimlere özgü özelliklerin ortadan kalkmasına yol açacaktır. Bu nedenlerle III. fikranın 1. cümlesinde TBMM seçimleriyle bağlantı kuran ibarenin maddeden çıarılması gerekir.

Bu arada savaş nedeniyle yerel seçimlerin geri bırakılması konusundaki boşluğun giderilmesi için III. fikraya Taslağın 78. maddenin I. fikrasına paralel bir hüküm konması yerinde olur.

\section{Madde 127 [Kamu Hizmeti Görevlileriyle Igili Hükümler]}

Sermayesi Devlete ait işletmeler niteliğindeki kamu iktisadi teşebbüslerinin verimlilik ve kârlılık ilkelerine göre çalışabilmeleri ve karma ekonominin mantiğı içinde özel kesimle eşit koşullar altında ya ruşabilmeleri, bu işletmelerde çalışanlar memur statüsü içinde kalđıkça olanaksızdır. Kaldı ki kamu iktisadî teşebbüslerinin çoğunun yaptı̆̆ı iş, kamu hizmeti nieliğinde değildir (krş. 233 sayılı Kamu İktisadî Teşebbüsleri Hakkunda Kanun Hükmünde Kararname m. 2/2-3). Bu nedenlerle maddenin I. fikrasındaki "kamu iktisadî teşebbüsleri" ibaresinin çkarilması gerekir.

\section{Madde 129 [Ÿ̈ulksekögretim Kurumları]}

Yüksek ögrretim kurumlan açılmasında Devlet tekeli sistemine dönmek, bu alanda hem bütün kaynaklarm harekete geçirilmesine, hem değişik sistemlerin denenmesine engel olacaktır. Işin ticarł kazanç 
konusu yapılmasına fırsat vermemek, Devletin gözctim ve denetimi altında olmak kaydıla; kamuya yararlı vakfflarca yüksek öğretim kurumları açılmasına olanak vermek, bilimsel araştırmalarda ve yüksek öğretimde çok seslilik ve dinamizm sağlayabilir. O nedenle maddeye bu yolda bir hüküm eklenmesi yerinde olur.

\section{Madde 140 [Mahkemelerin Kuruluşu - Devlet Güvenliks Mahkemeleri]}

Bu maddeye --sistematik bakımdan 1961 Anayasas''nn 20.3.1973 tarih ve 1699 sayıl Kanun'la değişik 136. maddesinde oldnğu gibi-. devlet güvenlik mahkemeleri ile ilgili bir düzenlemenin eklenmesi, yerinde olur. Türkiye'de devlet güvenlik mahkemeleri kurulmasını gerektiren nedenler, ülkenin karşı karşıya bulunduğu tellikẹler henüz: ortadan kalkmıs değildir. O nedenle şimdiye kadarki uygulamada eleştirilen yönlerini düzeltmek kaydıyla, bu mahkemeleri bir wzmanhk mahkemesi olarak biçimlendirmek ve sorunu gerçekçi bir yaklaşımla ele almak gerekir. Bu bakımdan Komisyon çoğunluğunun ilk toplantısinda 143. madde olarak kabul ettiği metin, üzerinde durulmaya değer bir düzenleme niteliğindedir.

\section{Madde 142 [Anayasa Mahkemesi]}

1. Anayasa Mahkemesi'ne Üniversitelerarası Kurul veya Türkiye Barolar Birliği Genel Kurulunca sẹçilecek üyelerin bu kurullarm "kendi üyeleri dışndan" olması zorunluğu, gereksiz bir kısıtlamadır. Üniversitelerarası Kurul üyesi olmak veya Türkiye Barolar Birliği Genel Kuruluna delege seçilmiş olmak, Anayasa Mahkemesi’ne üye seçilmeyi engellememelidir. Nitekim aynı kurullarca Hâkimler ve Savcılar Yüksek Kurulu üyeliğine öğretim üyesi veya avukat seçilmesi ile ilgili hükümde böyle bir kssitlamaya gidilmemiştir (krş. Taslak m. 154/I).

2. I. fikrada Anayasa Mahkemesi raportörlerinin doğrudan doğruya Mahkemece üye seçilmesi düzenlendikten sonra, III. fikrada yine raportörlerin Yargıtay, Danıştay ve Universitelerarası Kurul kontenjanlarından seçilmesine olanak tanımak gereksizdir. Anayasa Mahkemesi üyelerinin hep aynı çevreden gelmesi sonucunu doğurabilecek böyle bir uygulama, Anayasa Mahkemesi'ne Yargitay, Danıştay ve Üniversitelerarası Kurul'ca yeni isimlerin seçilmesine veya aday gösterilmesine engel olabilecek niteliktedir. $\mathrm{O}$ nedenle III. fikra metinden çıkarılmahdır. 
3. Maddenin IV. fikrası önceki fikralarla gereksiz yinelemelere yer vermeyecek biçimde yeniden yazılmalıdır.

\section{kileri]}

Madde 144, 149 [Anayasa Mahkemesinin Görev ve Yet-

1. II. fikrada "Cumhuriyetin değişmezliği ve bu ilkeyi değiştiren öneri yasağı, biçim denetimi kapsam?" içine alan hüküm, gerçekte Anayasa değişikliklerinin esastan incelenmesi sonucunu doğuracaktır. Anayasa Mahkemesi'nin 1961 Anayasası dönemindeki uygulaması, özellikle 1961 Anayasası'nın 20.9.1971 tarih ve 1488 sayli Kanun'la değişik 38. maddesinin kamulaştırma bedelini vergi değeri ile sınırlayan II ve III. fikralarmı iptal eden 12.10 .1976 tarih ve E. 1976/38, K. 1976/ 46 sayılı kararı, bu kavramlarm ne kadar geniş yorumlanmaya ve biçimden esasa girmeye elverişli olduŏ̌unu göstermiştir (bk. Anayasa Mahkemesi Kararlar Dergisi, S. 14, Ankara 1977, s. 252-286).

Anayasa değişikliklerinin esastan incelenmesi ise, toplumsal gelişme ve değişimlerin Anayasaya yansımasını engelleyebilecek niteliktedir. Bu bakımdan II. fıkranın metinden çıarlması uygun olur.

2. Aynı nedenle 149. maddenin V. frkrası 4. bendindeki "Anayasa değişikliklerinin" ibaresinin metinden çıkarılması gerekir.

\section{Madde 145 [Anayasa Mahkemesinin Yargalama ve Çaluşma Usulleri]}

I. fikranin 2. cümlesinin "Toplanttlarda kıdem ve uzmaplik gözetilir." biçiminde değiştirilmesi, hem Anayasa Mahkemes'nin yeni üyelerinden daha başlangıçtan itibaren yararlanmak, hem II. fukra ile paralellik sağlamak bakımından yerinde olacaktır.

\section{Madde 168 [Anayasamun Değiştirilmesi]}

Maddede Anayasa 'değişikliklerinin halkoylamasına sunulması usulüne yer verilmemiştir. Bilindił̌i gibi Türkiye'de 1961 ve 1982 Anayasaları halkoylamasıyla onaylanmıs; aynı usul, belirli koşullarla 1982 Anayasası'nu 175. maddesiyle Anayasa değişiklikleri için de benimsenmiş ve bu maddede I7.5.1987 tarih ve 3361 saylh Kanun'la yaplan değişiklikle pekiştirilmiştir. Anayasa değişikliklerinin egemenlǐ̆in asıl sahibi olan ulusun onayından geçirilmesi usulünün terk edilmesi anla- 
muna gelen yeni düzenleme ile daha önce vatandaşlara tanınmış bir hak geri alınmaktadır. Oysa Anayasa değişikliklerine ilişkin şimdiye kadarki halkoylamaları, bu hakkın ne kadar bilinçli ve sağduyulu kullanıldığını göstermiştir.

Kald ki seçimle milletvekillerine verilen temsil yetkisi, kural olarak toplumsal sözleşme niteliğindeki Anayasayı değiştirme yetkisini içermez. Belki sadece parlamentoda çok geniş bir uzlaşma ile, örneğin üye tamsayısının beşte dördünü aşan bir çoğunlukla kabul edilen Anayasa değişikliklerinin halkoylamasına gerek kalmaksızın yürürlüğe konması düşünülebilir.

Anayasa değişikliklerinin halkoylamasına sunulması, katılımcı demokrasi anlayı̧ına uygun olduğu kadar ülkemizde demokrasinin yerleşmesi ve gelişmesi, halkın demokrasiye sahip çımması bakımından da gerekli ve yararhdur.

\section{DIL, USLOP VE IML. $\hat{A}$}

Taslağın yazımında Öztürkçe tutkusu uğruna yer yer aşırılı̆̆a gidilmiş; yerleşmiş ve alı̧̧ılmuş ifade biçimleri terk edilmiş, dil ve üslûp zorlanmı̧̧tır. Duru ve arı Türkçe yazmak ortak istek olmakla birlikte; bu, düşüncenin zayıf ve yetersiz ifadesi pahasına yapılmamalıdır. Ayrıca hazırlanan Taslağın herkesce kolaylıkla anlaşılması gereken bir metin olduğu unutulmamalıdır. Bu nedenlerle aşırılık ve zorlamalardan kaçınmak gerekir.

Ote yandan Taslak'ta ayn maddelerde, hatta bazen ayn maddede eşanlaml eski ve yeni sözlükler kullanılmıştır. Imlâ ve noktalama işaretlerinde de tutarsızlılar görülmektedir. Taslağa son biçimi verilirken terim ve üslûp birliğinin sağlanması, imlâ ve noktalama işaretlerinde ortak kurallara uyulması için baştan sona kadar dikkatle gözden geçirilmesinde yarar vardır. 